\title{
Locke on Reason, Revelation, and Miracles
}

\author{
Nathan Rockwood
}

\begin{abstract}
The aim of this chapter is to explain why Locke thinks religious belief requires evidence and, on his view, what evidence there is for religious belief. I will explain and defend Locke's view that revelation can provide evidence for religious beliefs so long as there is evidence that God revealed it. Further, I will show how he takes the historical evidence of the miracles of Jesus as justification for belief in Christianity.
\end{abstract}

Locke insists, perhaps more so than anyone else, that religious belief requires evidence. Although this view is not unique to Locke, his articulation of this point has been especially influential and has even been called 'the single most important source' of this view (Plantinga 2000: p. 72). Yet some contemporary religious epistemologists have singled out Locke for criticism precisely for insisting that religious belief requires evidence (e.g., Wolterstorff 1996; Plantinga 2000). It will be worthwhile, then, to reconsider why Locke thinks religious belief requires evidence and, on his view, what evidence there is for religious belief.

There are two kinds of evidence that Locke appeals to in support of religious belief: natural theology and revelation. Natural theology is the attempt to use reason and observation (independent of any revelation) to justify religious beliefs. Locke thinks that natural theology can prove the existence of God (4.10) and determine God's commands (2.28.8). I will take these points for granted. Instead, the focus here will be on Locke's justification for belief in revealed religion. On Locke's view, it is revelation that provides evidence for most religious belief, though, as I will explain, he does appeal to natural theology in support of revelation.

The evidence for religious belief also comes in degrees. If the evidence entails the truth of a belief, then Locke will consider it certain 'knowledge.' For Locke, though, belief in revealed religion always falls short of certainty. In such a case, Locke insists that 'the mind, if it will 
proceed rationally' ought to base belief on the 'grounds of Probability' (4.15.5, my emphasis). So, as the second degree of evidence, if the evidence makes it likely a belief is true, it is a 'rational' belief. Finally, it is not rational to believe something without supporting evidence. While the latter point seems to be obviously true in most cases, some have thought that faith or religious belief is a notable exception. Locke, however, insists that 'our Assent' to the tenets of revealed religion 'can be rationally no higher than the Evidence of its being a Revelation.' Thus, while faith is often used 'in contradistinction to Reason,' Locke takes faith to be 'nothing else but an Assent founded on the highest Reason' (4.16.14).

Locke goes so far as to claim that we have a divinely imposed obligation to form beliefs based on evidence. He insists that it 'is our Duty' to accept religious claims as true only 'upon good Reason' and asserts, 'He that believes, without having any Reason for believing...neither seeks Truth as he ought, nor pays the Obedience due to his Maker' (4.17.24, my emphasis). God commands us to form beliefs based on evidence! Further, since we can know God's commands, he apparently thinks we can be aware of this obligation. What evidence, then, does Locke think there is for religious belief?

In this chapter, I will explain and defend Locke's view that revelation can provide evidence for religious beliefs so long as there is evidence that God revealed it. Further, I will show how he takes the historical evidence of the miracles of Jesus as justification for belief in Christianity.

\section{REVELATION AS EVIDENCE}

Locke holds that divine revelation can provide evidence for religious belief, but only if we first have evidence that God revealed it. 
The kinds of evidence Locke considers include reason, empirical observation, and testimony. Both a priori reasoning and direct empirical observation provide certainty, whereas reasoning (based on past experience) about an unobserved case provides probabilistic evidence (see Marušić and Priselac in this volume). I will call this 'direct evidence' in order to contrast it with testimony (see 4.19.10). Suppose, for example, that, while on the phone, Sophia tells Daniel that 'the cat is on the mat.' Daniel, who is not present and thus cannot see the cat or the mat, has no direct evidence about whether the cat really is on the mat. Yet, assuming Daniel has evidence that the testimony of Sophia is reliable, then it is most likely true, given Daniel's evidence (i.e., Sophia's testimony), that the cat is on the mat. So, Sophia's testimony indirectly provides Daniel with evidence that the cat is on the mat. Revelation, as God's testimony, can likewise provide evidence in the same kind of way. But revelation is even better evidence than human testimony because, as Locke puts it, God 'cannot deceive, nor be deceived' (4.16.14).

Enthusiasm, as Locke presents it, is a religious practice in which people claim to receive direct communication from God. (Locke seems to be targeting the Quakers; see Pasnau and Boespflug in this volume). The Enthusiasts point to a subjective feature of their experience as evidence that it comes from God: the revelation, they say, comes as a 'Light from Heaven' that 'carries its own' evidence (4.19.8). To the Enthusiasts, (i) it feels as though God is causing their revelatory experience and (ii) the revelation seems to them to be true. In Locke's estimation, however, neither of these subjective features provide evidence for the revelation: 'all the Light they speak of is but a strong, though ungrounded perswasion' and 'our Perswasions are no Evidence at all of their' truth (4.19.11, my emphasis). Thus, Locke (wrongly, in my view) holds that the subjective features of the Enthusiasts' revelatory experiences do not provide evidence that they have actually received revelation. 
Without evidence for revelation, revelation cannot be evidence for religious belief. Modifying a case presented by Lawrence BonJour (1980), we can imagine Norman the Enthusiast who receives a revelation but has no evidence of this:

Suppose Norman believes that God has revealed that $p$ to him and for this reason Norman comes to believe that $p$ is true. Further, suppose God really did reveal that $p$ to Norman. However, Norman has no evidence whatever that he received a genuine revelation from God or (absent the claim to revelation) that $p$ is true.

While Norman takes his claim to revelation as evidence that $p$, Locke objects that 'Enthusiasm fails of the evidence it pretends to' (4.19.11). He argues:

The question then here is, How do I know that GOD is the Revealer of this to me; that this Impression is made upon my Mind by his holy Spirit, and that therefore I ought to obey [or believe] it? If I know not this... it is groundless; whatever Light I pretend to, it is but Enthusiasm. (4.19.10, my emphasis)

Without any evidence that God revealed that $p$, Norman's belief that $p$ would be 'groundless' and, as Locke goes on to say, Norman's conviction that he received a revelation is 'mere Presumption' (4.19.10). Since this supposed revelation is his only reason for believing that $p$, he likewise lacks evidence for his belief that $p$. From the point of view of his own reasons for believing $p$, it would just be a stroke of luck if $p$ happened to be true. Intuitively, then, Norman's belief that $p$ seems irrational when assessed from his own point of view (BonJour 1980). This suggests that Norman's belief is unjustified and he ought not believe that $p$. The point here is that, even if God did in fact reveal that $p$ to Norman, his believing that $p$ would be rationally unjustified without evidence that God revealed that $p$.

Norman's situation would change entirely if he had (adequate) evidence that God revealed to him that $p$. For, since God's revealing that $p$ entails $p$ is true (4.18.10), if he had evidence that God revealed that $p$ this would thereby provide evidence that $p$. Further, 'there is need of no other Proof' than the evidence that God revealed it (4.19.11). Even if Norman lacked 
any direct evidence that $p$ is true, evidence that God revealed that $p$ nonetheless provides evidence from testimony that $p$ is true. In that case, it would be rational for him to believe that $p$.

The more interesting kind of case is when we have evidence that God revealed that $p$ but this conflicts with our direct evidence. For instance, if we know with certainty that $p$ is false then we should never believe that $p$, notwithstanding any evidence that God supposedly revealed that $p$ : 'For Faith can never convince us of any Thing, that contradicts our Knowledge. Because though Faith be founded on the Testimony of GOD...yet we cannot have an assurance of the Truth of its being a divine Revelation, greater than our own knowledge' (4.18.5). Here Locke implies that we can never be certain that God revealed that $p$; we can, at best, have evidence that makes this likely to be true. Further, the certainty that $p$ is false would outweigh any probabilistic evidence that God supposedly revealed that $p$. Thus, given our evidence, we should reject any supposed revelation when we know with certainty that the proposition is false.

Next, consider a case in which there is probabilistic evidence that God revealed that $p$ but this conflicts with probabilistic evidence that $p$ is false:

Suppose Isabella has reasonably good evidence that God revealed that 'there will be a resurrection at the last day' and thus she has some (indirect) evidence to believe this is true. However, she recognizes that this is unlikely to be true given her direct evidence (e.g., her past observations and understanding of science).

What should Isabella believe? According to Locke, she ought to believe whatever is most likely to be true given her available evidence (4.15.5). If the direct evidence outweighs the evidence that God revealed that there will be a resurrection, then she ought to believe there will not be a resurrection. But, and this is the point, if her evidence that God revealed that there will be a resurrection outweighs her direct evidence to the contrary, then she ought to believe in the resurrection. In this way, revelation can provide a rational basis for believing propositions that otherwise would lack evidential support (Wolterstorff 1996: p. 128; cf. Weinberg, forthcoming). 
In several passages, Locke asserts that revelation ought to be believed over probabilistic

evidence to the contrary:

Revelation...must carry it, against the probable Conjectures of Reason. Because the Mind, not being certain of the Truth that it does not evidently know, but only yielding to the Probability that appears in it, is bound to give up its Assent to such a Testimony, which, it is satisfied, comes from one, who cannot err, and will not deceive. (4.18.8, my emphasis)

...in those [matters], concerning which it has but an uncertain Evidence, and so is perswaded of their Truth, only upon probable Grounds... in such Propositions, I say, an evident Revelation ought to determine our Assent even against Probability. (4.18.9, my emphasis)

It may be tempting to interpret Locke here as saying that revelation that $p$ ought to be believed no matter what the probability is, given the direct evidence, that $p$ is false (Weinberg, forthcoming). But elsewhere he insists that religious belief be based on 'the clearer Evidence, and greater Probability' (4.17.24). So, instead, the point seems to be that if the probability that God revealed that $p$ is higher than the probability that $p$ is false, then we should believe that $p$ (Wolterstorff 1996: p. 131). Notice that, in the above passages, Locke says we should believe an 'evident revelation' and one we are 'satisfied' comes from God. Thus, Locke takes it to be already established that God revealed that $p$, and the question is then whether it ought to be believed given the contrary evidence. Since a revelation is guaranteed to be true, Locke asserts that, if given our overall evidence we take $p$ to be a revelation, the revelation should be believed in the face of (lesser) contrary evidence.

There are several significant lessons to be learned from the above discussion about Locke's view of revelation as a kind of evidence:

1. In order for revelation to provide evidence for religious belief, there must first be evidence that it is a revelation. 
2. If we lack direct evidence that $p$ is true, it can nonetheless be rational to believe that $p$ on the basis of a revelation (if we have evidence that God revealed that $p$ ).

3. Even if the direct evidence concerning $p$ conflicts with revelation, it can nonetheless be rational to believe the revelation that $p$ (if the evidence God revealed that $p$ outweighs the direct evidence that $p$ is false).

While I take this to be a rather plausible position, there are two sources of controversy. First, some religious epistemologists, such as Plantinga and Wolterstorff, reject thesis (1). On their externalist theory of justification, rational belief does not always require being aware of evidence. But even if that were so, these theorists ought to concede theses (2) and (3). Second, there is, of course, disagreement about whether we actually have good evidence for any divine revelation. I would think the most plausible evidence here would be religious experience, but above we saw Locke reject the view that subjective features of our experience can provide good evidence for revelation. In the next section, then, I discuss what evidence there is, on Locke's view, for divine revelation.

\section{EVIDENCE FOR REVELATION}

Locke holds that revelation can provide evidence for religious belief, but only if there is evidence that the revelation actually came from God. So, what evidence is there for revelation? Locke's answer: miracles. Locke uses miracles to argue both for the truth of Christianity over other revealed religions as well as to argue against deism, which accepts natural theology but rejects revealed religion. Although the argument from miracles was not new to Locke (see Craig 1985 for antecedents), Locke's insistence on the need for evidence supporting Christianity and his appeal to miracles as that evidence gave new importance to the argument from miracles (Orr 1934; Craig 1985). Locke's argument from miracles has not aged well, however, mostly because 
of David Hume's critique. Below I argue Locke's defense of belief in miracles is more plausible than often supposed, which opens the door for reasonable belief in the argument from miracles.

His appeal to miracles is most obvious in The Reasonableness of Christianity and the posthumously published $A$ Discourse of Miracles. The former is an apologetic work in which Locke repeatedly argues that the miracles of Jesus justify belief in Christianity. He argues, for example, that 'we see the people justified their believing in him, i.e., their believing in him to be the Messiah, because of the miracles he did' (Reasonableness: p. 32, my emphasis). In $A$ Discourse of Miracles, Locke sets out to define 'miracle' and specify the conditions under which the testimony of a miracle should be accepted. There, he goes so far as to claim that miracles are 'the only means God is conceived to have to satisfy men, as rational creatures, of the certainty of any thing he would reveal, as coming from himself...' (Discourse of Miracles: p. 262, my emphasis). In these passages, and others like them (e.g., Reasonableness, pp. 49, 84-85, 108, 341; Discourse of Miracles, pp. 259, 261, 264), Locke clearly asserts that miracles provide evidence for revelation, and in particular he cites the miracles of Jesus as evidence for the truth of Christianity. Further, as we just saw, he claims that miracles are the ONLY acceptable evidence for revelation.

A similar theme shows up in the Essay. He claims, 'Miracles... well attested, do not only find Credit themselves; but give it also to other Truths, which need such Confirmation' (4.16.13). Even the ancient prophets 'who had Revelations from GOD' did not rely solely on 'that internal Light,' but instead 'had outward Signs to convince them of the Author of those Revelations;' they likewise justified to others their claims to revelation 'by visible Signs' (4.19.15, my emphasis). In order to avoid the perils of Enthusiasm, which appealed only to private religious 
experiences as evidence of revelation and which lead to 'extravagant Errors' (4.19.11), Locke is driven to miracles as a kind of publicly available evidence.

In retrospect, one obvious objection to Locke's approach is that it is not rational to believe in the testimony of miracles, and so belief in miracles is an implausible basis for believing in revealed religion. Deists and, later, Hume saw Locke's reliance on the argument from miracles and then attacked the belief in miracles, thereby undermining the argument for Christianity (Orr 1934; Craig 1985). Hume, for example, famously objects that the testimony of a miracle conflicts with all of our past experience and therefore should be rejected as too improbable to be believed.

However, while Locke takes observed regularities to be evidence relevant to making judgments about the probability of naturally caused events (4.16.6-9), he thinks that an exception should be made in the case of miracles:

Though the common Experience, and the ordinary Course of Things have justly a mighty Influence on the Minds of Men, to make them give or refuse Credit to anything proposed to their Belief; yet there is one Case, wherein the strangeness of the Fact lessens not the Assent to a fair Testimony given of it. For where such supernatural Events are suitable to ends aim'd at by Him, who has the Power to change the course of Nature, there, under such Circumstances, they may be the fitter to procure Belief, by how much the more they are beyond, or contrary to ordinary Observation. This is the proper Case of Miracles, which well attested, do not only find Credit themselves; but give it also to other Truths, which need such Confirmation. (4.16.13, my emphasis)

Locke's move here is to argue that observed regularities in the ordinary course of nature are not relevant to making judgments about whether or not a miracle occurred. For, if God wants to perform a miracle under certain conditions then, given that he can do so, it seems likely that he would do so in those conditions; what happens in other cases, where God does not want to intervene in the normal course of nature, is irrelevant. 
Unlike many, I think Locke gets the better of Hume in this exchange. Hume's argument has been tremendously influential, and even believers in miracles tend to grant the thesis that past experience makes the occurrence of any miracle unlikely. But, as a general principle of induction, observed cases give us good evidence about unobserved cases only if the former and the latter are relevantly similar. (For example, polling a sample of Democrats can give us good evidence about the views of Democrats in general because the polled Democrats are presumed to resemble other Democrats, but such a poll would not give us good evidence about the political views of Republicans.) In Locke's view, naturally caused events are similar to other naturally caused events and so our past experience of natural events is good evidence concerning (for us) unobserved natural events. But he reasonably denies that naturally caused events are relevantly similar to a putative case in which there was divine intervention. So, past observations of natural events do not provide good evidence against the testimony of a miracle. (For a further defense of this point, see Rockwood 2018.)

Further, Locke believes that there are positive reasons to expect miracles under certain conditions. Locke thinks he can establish, prior to any appeal to revealed religion, that God exists and wants us to form rational beliefs (see the introductory section above). And, as Wolterstorff rightly argues, Locke holds that, since God wants us to rationally believe revelation, God would never give revelation without also providing evidence that he has done so (Wolterstorff 1996, pp. $120-121 ; 4.19 .14)$. But notice further that, as I pointed out above, Locke takes miracles to be the one and only kind of acceptable evidence for revelation (again, see Discourse of Miracles: p. 262). So, if God reveals that $p$ then God will also perform a miracle to confirm that revelation. Locke argues, for example, that the religious Enthusiast should put 'his Light within to the Tryal,' for if it were a genuine revelation God would provide 'some Marks' (i.e., miracles) that 
the truths were revealed by God (4.19.14). This commitment to providing us with evidence is why, in 4.16.13, Locke says that it is fitting to believing the testimony of miracles when such would confirm a claim to revelation.

According to the interpretation I have described above, there are two main considerations that contribute to Locke's acceptance of miracles as evidence for revelation. First, unlike Hume, Locke does not take our past observation of natural events as evidence against the testimony of a miracle. Second, he thinks we have independent grounds for believing that God is likely to perform a miracle in order to confirm revelation. From Locke's perspective, then, it can be reasonable to take miracles as the basis for believing in revealed religion.

Locke thinks that the argument from miracles provides especially strong evidential support for Christianity, as opposed to other revealed religions. As noted above, God would not reveal that $p$ without providing adequate evidence, by the performance of miracles, that $p$ is indeed a revelation. Further, when there are competing religious traditions, both of which appeal to miracles, 'the evident marks of a greater power' is 'unquestionable evidence' of the genuine revelation. For, Locke argues, God is unwilling to let us be led astray by false evidence of divine revelation:

God can never be thought to suffer that a lie, set up in opposition to a truth coming from him, should be backed with a greater power [or evidence] than he will show for the confirmation and propagation of a doctrine which he has revealed... (Discourse of Miracles: p. 260, my emphasis).

According to Locke, God will always make sure that the greater evidence, by means of greater miracles, will substantiate genuine revelation (Dumsday 2008). He then argues that 'the number, variety, and greatness of the miracles' of Jesus so far exceed that of any other tradition that we should believe his claims to revelation (Discourse of Miracles: p. 261). Thus, it is the superiority of the miracles of Jesus that provides evidence in favor of Christianity. 
Locke also thinks that the argument from miracles has force against deism. This is perhaps surprising given that a distinctive feature of deism is its rejection of divine intervention, including miracles (Orr 1934: p. 14). It seems, then, that deists would simply reject the premise of Locke's argument for Christianity. Nonetheless, Locke says he 'chiefly designed' The Reasonableness of Christianity to convince deists to believe in Christianity (Reasonableness: $\mathrm{p}$. 265). Locke was not alone in employing this strategy. As William Craig documents, the argument from miracles was actually developed by Grotius and others in direct response to the rise of deism (Craig 1985, pp. 71-82). But why does Locke (among others) think the argument from miracles would or should work as an argument against deism? The answer, in short, is that Locke believes natural theology establishes a motive for divine intervention by way of revelation and miracles.

According to Locke, natural reason can prove that an omnipotent God exists who, crucially, cares about human affairs. As noted above, he holds that reason can establish both that God wants us to act rationally (including acting morally) and to believe rationally. Given these assumptions, God would make sure we have sufficient evidence about what our moral duties are. However, while Locke is confident that reason alone can demonstrate moral truths (e.g., 3.9.16), no one has yet done so (Reasonableness: p. 139-140) and, in any case, such demonstrations would not be evident to the masses. So, one motive for divine revelation is that God wants to tell us, in such a way accessible to all, what our moral duties are. A second motive is God's concern for our eternal welfare; God wants to tell us what the requirements for salvation are. Locke's natural theology, then, can establish a motive for God to give revelation. This argument should have some purchase against the deist position since they agree that God cares about human conduct (Orr 1934: p. 15). The main point of disagreement between Locke and the deists is this: 
the deists insist that natural theology tells us all we need to know, and (while he does not wholly disagree) Locke insists that the easiest and most effective way for God to inform us of our moral duties is the revelation given through Jesus Christ, backed up by the miracles he performed (Reasonableness p. 147; Discourse of Miracles: p. 264). By establishing a divine motive for revelation, Locke can then expect that God would occasionally reveal truths about morality and salvation. And if there is revelation, then there will be miracles as substantiating evidence of the revelation.

Matthew Bagger argues that Locke is guilty of 'evidential circularity' (Bagger 1997: p. 242). He argues, 'Remember that [Locke] founds belief in Christian revelation on miracles...' and yet 'he permits belief in the anomalous event that constitute the miracle because, when they accompany revelation, their strangeness renders them 'suitable to ends aimed at by Him,' the God of Christian revelation' (p. 242). But, contrary to Bagger's claim, there is no circle here. (Notice that it is Bagger who adds the clause 'God of Christian revelation'; that, on my interpretation, is a point to be justified by the miracle and not the justification for belief in the miracle.) First, Locke takes natural theology to establish that (i) God exists, (ii) God has a motive for giving revelation, and (iii) if God reveals that $p$ then he would confirm that revelation with a miracle. Given these points, Locke thinks, in general, it would be reasonable to believe a credible claim that a miracle occurred in confirmation of a revelation. Second, Locke argues for the truth of Christianity within this framework: there is credible testimony that Jesus rose from the dead (etc.), and this would, if believed, confirm his claim to revelation. The evidence, then, moves in a straight line from natural theology, to believing the testimony of the miracles of Jesus, to believing in Christianity. Locke is thus absolved of the charge of circularity. 
It may be useful here to, again, briefly summarize and evaluate Locke's central theses, but this time with respect to his view of miracles as evidence for revelation:

1. Miracles are the one and only acceptable kind of evidence for revelation.

2. It can be rational to accept the testimony of a miracle (if there is independent reason to believe that God would perform a miracle in such a case).

3. God would not reveal that $p$ without providing us with evidence that he has done so.

Thesis (1) is certainly a mistake. Even if miracles can provide evidence for revelation, in my view, religious experience (among perhaps other things) can also provide evidence for revelation. This, in turn, weakens Locke's argument that we should expect God to perform miracles as evidence for revelation. Thesis (2), it is needless to say, remains a point of significant controversy. Perhaps the most interesting of the above, though, is thesis (3). Locke has unfailing confidence that God wants us to form beliefs based on evidence, including with respect to religious beliefs. This commitment, I suggest, is the underlying motivation in Locke's evidentialist epistemology.

The overarching theme in Locke's epistemology is the need for evidence, and we have seen that, on Locke's view, God is invested in providing evidence for religious belief. God reveals to us certain truths that are important for us to believe and, given God's infallible testimony, we thereby have indirect evidence for these revealed truths. In my estimation, this position is quite plausible. Locke is clearly right that if we have good evidence that God revealed that $p$ then this would provide us with evidence that $p$. In this way, revelation could justify religious belief. The two points of controversy are, first, whether religious belief requires evidence and, second, whether there is such evidence. Locke's insight, in part, is that these two issues go together: if God exists, and religious belief requires evidence, then there is guaranteed 
to be evidence in support of religious belief. So, on his view, if God revealed that $p$ then he would provide us with evidence that he has done so. In that case, as Locke says, faith in revealed religion would be 'nothing else but an Assent founded on the highest Reason' (4.16.14).

\section{RELATED TOPICS}

God, Enthusiasm, knowledge, probability

\section{REFERENCES}

BonJour, Lawrence (1980), 'Externalist Theories of Empirical Knowledge,' Midwest Studies in Philosophy v. 5.

Craig, William Lane (1985), The Historical Argument for the Resurrection of Jesus During the Deist Controversy (The Edwin Mellen Press).

Orr, John (1934). English Deism: Its Roots and Its Fruits (WM. B. Eerdmans Publishing Company).

Plantinga, Alvin (2000), Warranted Christian Belief (Oxford University Press).

Rockwood, Nathan (2018), 'Hume on Laws and Miracles,' American Catholic Philosophical Quarterly v. 92, n. 4.

Weinberg, Shelley, "Locke on Reason, Faith, and Miracles," forthcoming in Journal of the History of Philosophy.

Wolterstorff, Nicholas (1996), John Locke and the Ethics of Belief (Cambridge University Press).

\section{FURTHER READING}

Dumsday, Travis (2008), 'Locke on Competing Miracles,' Faith and Philosophy v. 25, n. 4. (This article is an exposition of $A$ Discourse of Miracles. Locke there argues the miracles of Jesus can provide evidence for Christianity notwithstanding reported miracles from other, incompatible religious traditions.) 
Nuovo, Victor (2011), Christianity, Antiquity, and Enlightenment: Interpretations of Locke (Springer). (Chapter 8 includes a clear and concise exposition of The Reasonableness of Christianity. As the name of that work implies, Locke argues that belief in Christianity, as he defines it, is rational.)

* Thanks to Jessica Gordon-Roth, Gordy Mower, Lex Newman, Katie Paxman, Eric Stencil, Carlos Santana, and Shelley Weinberg for their thoughtful comments on an earlier draft of this chapter. 